\title{
Kuramsal Bir Gelenek Olarak Tarihsel Kurumsalcılık ve Uluslararası İlişkiler
}

Fatih DEMIRCIOĞLU ${ }^{l}$

Öz

Bu çalışmada tarihsel kurumsalcılı̆̆ın sosyal bilimler ve uluslararası ilişkiler içerisindeki seyri açıklanmış ve ilgili literatürden örneklere başvurmak suretiyle uluslararası sistemin evrimi tarihsel kurumsalcı yöntemin kavramlar seti aracılığıyla anlamlandırılmaya çalışılmıştır. Uluslararası sistemin kurumsal değişim ve dönüşümü üzerinde etkili olan tarihsel kurumsalcı gündemlerden ve kademeli değişim modellerinden bahsedilmiştir. Tarihsel kurumsalcıllı̆ın, kurumsalcı geleneğin diğer yaklaşımlarıyla olan farkları vurgulanarak bu yöntemin Uluslararası İlişkiler Disiplini'nin olgunlaşmasına katk1 yapabilecek potansiyele sahip olduğu gösterilmiştir.

Anahtar Kelimeler: Tarihsel Kurumsalcılık, Uluslararası İlişkiler

\section{Historical Institutionalism as a Theoretical Tradition and International Relations}

\begin{abstract}
In this study, the historical institutionalism was explained in the course of social sciences and international relations and the evolution of the international system was tried to be understood through the set of concepts of historical institutionalist method by referring to examples from the related literature. Historical institutional agendas and models of gradual change that have impacted on institutional change and transformation of the international system have been mentioned. It has been demonstrated that this method has the potential to contribute to the maturation of the International Relations Discipline, emphasizing the differences between historical institutionalism and other approaches of institutional tradition.
\end{abstract}

Key Words: Historical Institutionalism, International Relations

\footnotetext{
${ }^{1}$ Arş. Gör., Kocaeli Üniversitesi, Uluslararası İlişkiler Bölümü, demircioglufatih @ hotmail.com Bu makale URKUND programı yardımıyla intihale karşı kontrol edilmiştir.
} 


\section{Giriş}

Bu makalede, bir kuramsal gelenek olarak tarihsel kurumsalcılığın uluslararası meselelerdeki hayati sorulara, analitik özellikleriyle yaptığı atıf ve genel olarak bu geleneğin uluslararası ilişkiler disiplinine yaptığı katkılar tartışılacaktır.

Tarihsel Kurumsalc1lı terimi ilk kez Ocak 1989'da Boulder, Colorado'daki bir buluşma sonucunda ortaya çıktı. Buluşmanın katı1ımciları arasında Douglas Ashford, Colleen Dunlavy, Peter Hall, Ellen Immergut, Peter Katzenstein, Desmond King, Frank Longstreth, Jonas Pontusson, Bo Rothstein, Theda Skocpol, Sven Steinmo, Kathleen Thelen, Geroge Tsebilis, ve Margeret Weir gibi akdemisyenler vard. Ardından 1992 y1lında "Structuring Politics: Historical Institutionalism in Comparative Politics (Steinmo, Thelen ve Longstreth 1992)" makalesi ile tarihsel kurumsalc1lı sosyal bilim içerisindeki yerini almış oldu. (della Porta ve Keating 2015)

Tarihsel kurumsalcı gelenek, uluslararası siyasal gelişim çalışmalarındaki yeni araştırma gündemlerini açıklamakta umut vaat etmektedir. Devlet tercihlerinin kökeni, yönetişim boşluklarının kaynağı ve uluslararası sistemdeki değişim ve devamlılığın doğası, başlıca gündem maddeleridir. Tarihsel kurumsalcılığın analitik yönünün ve asli özelliklerinin uluslararası ilişkilerdeki disipliner olgunlaşmaya olumlu yönde katkıda yapacağı öngörülmektedir.

\section{Tarihsel Kurumsalcılığın}

\section{Uluslararası İlişkiler Disiplini İçerisindeki Seyri}

Uluslararası ilişkilerdeki kurumsal dönüş, disiplinin olgunlaşmasına belirgin bir biçimde katkı sağlayan birçok sağlam araştırma programı üretmiştir. Realizm ve liberalizmin çeşitli sürümleri arasındaki paradigmatik savaşları disiplinin odağı konumundan çıkarıp uluslararası ilişkileri daha geniş bir boyuta taşımıştır. (Katzenstein, Keohane ve Krasner 1998)

Uluslararası İlişkiler disiplini günümüzde, bilimsel araştırmanın özenli ve ortak standartları, daha zengin ampirik temeller ve sosyal bilimler için yaygın ve ortak olan kavramların kullanımı ile karakterize olmaktadır. Disipliner olgunlaşmanın bu özellikleri, yaygın teorilerin değeri üzerine tartışmaların geride bırakılması ve uluslararası meseleleri açıklarken kurumsal teorilerin kullanılmasının bir sonucudur.

Uluslararası ilişkilerdeki kurumsal dönüş, Rasyonel Seçim Kurumsalc1lığı ve Sosyolojik Kurumsalcılık ile dikkatleri çekmiş; sosyal bilimlerin diğer alanlarına yapılan katkılar, kurumsalcı geleneğin bu iki dalının politika çalışmalarında da kullanılabileceği fikrini cesaretlendirmiştir. (Keohane ve Martin 2001; Snidal 2002; Milner 1998; Pollack 2006; Finnemore 1996; Finnemore ve Sikkink 2001) Ancak, bu iki alt dala nazaran, Uluslararası İlişkiler, çağdaş siyaset biliminin kurumsal geleneğinin üçüncü alt dalına, yani Tarihsel Kurumsalcılığa gereken önemi göstermemiştir. Bu ekol saha d1şında bırakılmıştır. (Carlsnaes, Risse ve Simons 2002; Reus-Smit ve Snidal 2008) 
Bir tarafta devlet merkezli Uluslararas1 İlişkiler disiplini ile rasyonel seçim kurumsalcılığı arasındaki, diğer tarafta sosyolojik kurumsalcılık ve uluslararası toplum yaklaşımları arasındaki sık1 yakınlık göz önüne alındığında, Uluslararası İlişkiler disiplinindeki kurumsal dönüşün, Realizm ve İdealizmin rakipleri olarak nitelendirilen kurumsalcılığın çatışan teorileri tarafından başlatılması gayet doğaldır. Ancak Uluslararası İlişkiler disiplininde kurumsal dönüşün hız kazanması, Siyaset Bilimi gibi sosyal bilimlerin diğer alt dallarını karakterize eden üç ayaklı kurumsalcı geleneğin, Uluslararası İlişkiler disiplini için neden iki ayaktan ibaret kaldığı sorusunun gündeme getirilmesi için iyi bir neden olmuştur.

Tarihsel kurumsalcılığın uluslararası ilişkilerdeki eksikliği, disipline özellikle çalışmanın konusu uluslararası kurumlardaki süreklilik ve değişim modelleri olduğu zaman bazı belirgin analitik ve ampirik firsatlara mâl olmaktadır.

Uluslararası İlişkiler akademisyenleri, yerel ve uluslararası politika çalışmaları arasındaki ayrımın azaltılması için kapsamlı çağrılarda bulunmalarına rağmen disiplinin, kurumsalcı geleneğin önemli bir yaklaşımını ihmal ediyor olması şaşırtıcıdır. Ayrıca, tarihsel kurumsalcılık, uzun vadeli güç ilişkilerini şekillendiren kuruluş anlarının mirasları, yeni fikirler önemli hale geldiğinde oluşan beklenmedik sonuçların heryerdeliği ve özellikle kademeli ve kökten dönüşümler üzerinde artan reformların yaygınlaşması gibi uluslararası ilişkileri karak- terize eden süreç tiplerinin önemine vurgu yapmaktadır. (Milner 1998; Martin ve Simmons 1998; Frieden ve Martin 2001)

Uluslararası ilişkiler, elbette tarih ile hiçbir bağı olmayan bir disiplin değildir. Hatta tam tersine tarih disiplinine çok şey borçludur. (Elman ve Elman 2001; Woods 1996) Ancak, genel anlamda uluslararası ilişkiler, tarihi kendi teorilerini geliştirmesini kolaylaştıracak ampirik temellerin sağlayıcısı olarak görmüştür.

Birçok uluslararası ilişkiler akademisyeninin karşılaştığı değişkenleri belirleme sorunu ele alındığında tarihsel arşiv sıklıkla, karş1laştırmalı vaka analizlerini de içeren, olay sayısını genişleten bir kaynak olarak görülmüştür.

Tarihsel kurumsalcılar için tarih, bağımsız olayların bir sıralaması değildir. Tarihe ciddiyetle yaklaşmak sonuçta araştırmacının değişkenlerin bağımsız şeyler olduğu düşüncesine kuşkuyla yaklaştığı anlamına işaret etmektedir. Tarihin önemine vurgu yapmak, değişkenlerin birbirini şekillendirebileceği ve genelde böyle olduğu konusunda bir anlayışı temsil eder. Tarihsel kurumsalcılar, değişkenlerinin karş1lıklı bağımlılı̆̆ üzerinde, diğer geleneklerdeki araştırmacılardan daha fazla durmaktadırlar. (della Porta ve Keating 2015)

Tarihsel kurumsalcilar, sosyal bilimlerde "her şeyin yasası"nı bulmaya dair heveslere şüpheyle yaklaşırlar, nomotetik öngörüyle değil açıklama ile ilgilenirler. Bu geleneğin temel varsayımlarından biri de evrensel ve her zaman geçerli bir yasanın olanaksız olmasıdır. Tarihsel kurumsalcılar, karşılıklı bağımlılı̆̆ı olan 
değişkenlerin zaman içindeki karmaşık etkileşimi sebebiyle bu tür yasalara ulaşılamayacağını düşünmektedirler. Tarihsel akış içinde, insanlar ve kurumlar değişir, uyum sağlar ve etkilenirler. Evrensel yasalara ulaşma çabası ve bununla bağlantılı bilimsel paradigma, dünyanın gerçeklerini reddeder. Sosyal bilimlerin incelemesi doğa bilimlerindeki gibi değildir ve olamaz, çünkü araştırma nesnesi ve açıklamak istediğimiz şeyler mutlak yasaların geçerli olduğu cansız nesneler değildir. (della Porta ve Keating 2015) Tarihsel kurumsalcı akademisyenler, tarihsel süreçler politik süreçleri nasıl ve ne zaman şekillendirir bununla ilgilenirler. Pierson, tarih ile olan bu yakınlaşmayı bir kuramsal dönüş olarak tanımlar ve disiplinin daha güncel çalışmalarında gözlenen bağlamından koparılmış devrimi onaracağını ve düzelteceğini belirtir. Ona göre, son raddede kuramsal dönüş, genel olanın açıklanması ve özel olanın anlaşı1ması arasındaki dengeye daha tatmin edici ve etkili bir katk1 sağlayacaktır. (Pierson 2004, s.178)

Bir disiplin hangi koşullar altında olgunlaşır konusunu inceleyen bir makalede Lake aynı genel kriteri benimsemekte ve Uluslararası İlişkiler disiplininin, akademisyenler ortak bilimsel araştırma standartlarını teşvik ettiklerinde, ampirik bilginin önemini vurguladıklarında ve sosyal bilimlerde ortak olan kavramlar kullandıklarında olgunlaştığını tartışmaktadır. (Lake 2002, s.136)

Tarihsel kurumsalc1lık, ulusal egemenliğin evrimi, uluslararası işbirliği ve uluslararası sistem gibi uluslararası politika çalışmaların- daki temel sorularla ilgilenmektedir. Savaş, barış, finans, ticaret, kalkınma, hukuk gibi uluslararası ilişkilerin birçok alanını kapsayan, on yı1lardan birkaç yüzyıla kadar sürebilecek uzun zamansal süreçlere odaklanır.

Temsilcilerinin çoğu kendilerini tarihsel kurumsalcı olarak tanımlamıor olsalar da hepsi, takip edecek gelişmeleri şekillendirmede kurucu anların rolü, kurumsal mirasların güç ve kaynak kullanımının derecesini nasıl etkilediği ve aşamalı artan uyumlama modellerinin kurumları zamanla hangi yollarla biçimlendirdiği gibi geleneğin özündeki temellerin altını çizmektedir.

Tarihsel kurumsalc1lik, ne bir siyaset teorisi ne de kurumsal gelişimin genel bir teorisidir. Rasyonel seçim kurumsalcılığı ve sosyolojik kurumsalcılık gibi analitik kavramlar ve yöntemlerin farklı bileşenlerden oluşan bir karışımı ile seçilmiş konular kümesine özel ilgi gösteren kuramsal bir gelenek olarak tanımlanır. (Mahoney ve Reuschemeyer 2003)

Tarihsel kurumsalcılığın en ayırt edici işareti, olayların zamanlama ve sıralanışının politik süreçleri şekillendirmesi şeklinde ifade edilebilecek zamansal bağlam konusuna verdiği önceliktir. Daha özel terimsel ifadeyle belirtecek olursak; tarihsel kurumsalcılık zamanlama ve sıralamanın, öngörülemezliğe, esnemezliğe, hesaplanamazlığa ve etkisizliklere katkı yapt1ğını savunur. (Pierson 2000 ve 2004). Bunlar, ne üzerinde uzlaşılamaz ne de yeni iddialardır. Fakat bunları somut veriler ve analitik terimler kullanarak ciddiye almak uluslararası ilişkilerdeki kurumsal çalışmalara yönelik farklı bir yaklaşım olması açısından katkı yapmaktadır. 
Tarihsel kurumsalcılar, politik olaylardaki zamanlama ve sıralamanın önemli olduğuna dikkat çekerler; çünkü kişi eylemleri ile şekillenen birçok kurumdaki firsatların ve sınırlamaların evrimi, genel olarak zaman içerisinde farklı türden oyunlar ortaya çıkarır. Özellikle politik aktörlerin kişisel hesapları ve hâlihazırda mevcut olan sistemden kaynaklanan sinırlılıkların doğası zamanla belirgin bir şekilde değişebilmektedir. Başka bir deyişle tarihsel kurumsalc1lık, zamansallığa (geçiciliğe) hayati bir önem atfetmektedir; çünkü takip edecek olan olaylar, öncekiler tarafından koşullandırılmıştır. Ayrıca bu gelenek disiplinin araştırma nesnesini sabit girdileri ve sonuçları olan bir şey olmaktan çıkarmakta ve kurumsal gelişimin dinamik ve çeşitli süreçlerini açıklamaya odaklanmaktadır. (Pierson 2004; Streeck ve Thelen 2005; Thelen 1999; Sanders 2006; Mahoney ve Thelen 2009)

\section{Tarihsel Kurumsalcılığı}

\section{Diğer Yaklaşımlardan Ayıran Unsurlar}

Tarihsel kurumsalcılık ve diğer gelenekler arasındaki analitik ve somut farkl11ıklar yaygın kabul görmüş olsa da bazı uluslararası ilişkiler akademisyenleri bu geleneğin kurumsalcı gelenek içerisinde kendine özgü bir konuma sahip olduğuna dair ve ayrı bir dal olmayı hak edip etmediği konusundaki şüpheciliklerini dile getirmişlerdir. (Stein 2008; Lawson 2006) Fakat tarihsel kurumsalcılık için merkezi önemi haiz kavramların diğer geleneklerde de kullanılıyor oluşu (veya tersi) bu kuramsal gelenek hakkında "ayrı bir dal olacak kıymette değildir" gibi bir yargıya varmak için uygun bir ölçüt değildir. Zira diğer iki kurumsalcı gelenek de di- ğer teorilerden yöntemler ve kavramlar devşirerek kendi kuramsal temellerine ve disipline katkılar yapmıştır.

Kurumsal çalışmaları diğer yaklaşımlardan ayırt eden şey, özel kavramlar ya da yöntemler kullanılması değildir. Daha çok, geleneğin bağımsız asli kapsamı ve özellikle siyasal süreçlerin şekillenmesinde kurumların rolü ve insan faktörüne atfettiği önemdir. Bu bağlamda değerlendirildiğinde tarihsel kurumsalcılık diğer iki kurumsal gelenekten birçok önemli noktada ayrılmaktadır. Tarihsel kurumsalcılığın bağımsız profili, zamansal kapsam ile belirginleşen sorular ve kurumların zaman içerisindeki yaratma, yeniden üretme, geliştirme ve yapısı ile ilgilenmektedir. (Pierson ve Skocpol 2001; Thelen 2004; Sanders 2006)

Ikenberry ve Raustiala, iki asırdan fazladır ulusal egemenliğin doğası ve uluslararası siyasal düzeni tanımlayan kurumların evrimini açıklamaya odaklanmışken; Newman, Barton ve Abdelal gibi yazarlar, uluslararası kurallar üzerinde politik pazarlıkların zamanlaması ve sıralamasının nasıl erken 21. yüzyılda uluslararası ilişkilerin doğasına dair beklenmeyen ve istenmeyen sonuçlar ürettiğini tartışmışlardır. (Ikenberry 2001; Raustiala 2009; Newman 2008; Barton vd. 2006; Abdelal 2007)

Tarihsel kurumsalcılığa farklı bir kuramsal kimlik kazandıran en önemli unsurlardan biri de ikinci-dereceden sorulardır. İkincidereceden kuramsallaştırma, analitik bir geleneğin aktörlerin tercihlerinin kökeni ve yapısını, insan faktörü kavramı ve insan davranışlarındaki sınırlamaları nasıl anladığına işaret eder. 
(Wendt 1999, s.4) Haddi zatında ikinci-dereceden sorular, fikirlerin ve aktörlerin rolü, çıkarlar ve kurumlar arasındaki ilişki, bunun yanı sıra kurumsal gelişimin çeşitli modellerinin ortaya konulmasında ön plana çıkan mikro-mekanizmalar gibi meselelerle ilgilenir.

Tarihsel, sosyolojik ve rasyonel seçim kurumsalcılı̆̆ gelenekleri arasındaki ikinci-derece farklılıklar, insan tercihleri ve eylemlerinin alternatif anlayışlarından kaynaklanmaktadır. Tercihler, Katznelson ve Weingast'ın deyimiyle; eğilimlerin, belirli koşullar altında ne yönde evrileceğini, kesin veya göreceli olarak muhakeme edilen alternatifler arasında ayrım yapacak kişiler aracılığıyla belirler. (Katznelson ve Weingast 2005, s.7)

Üç kurumsal gelenek, kişilerin fikirlerini eyleme geçirecekleri alternatifler üzerinde karar verme noktasında farklı varsayımlarda bulunurlar. Rasyonel seçim geleneğinde öncelikli husus, tercihleri şekillendiren ve eylemi motive eden şeyin nihai nokta karşılaştırmaları olduğudur. (March ve Olsen 1984) Olas1 aday alternatiflerden daha az maliyetli ve daha çok etkili olanı baskın gelir ve eylemi yönlendirir. Eğer bir alternatif, mevcut duruma göre daha olas1 görünüyorsa ve baskın ise aktörlerin tercihi, alternatif model lehine dönüşümü devreye sokmak olacaktır. Buna zit olarak tarihsel kurumsalcılar eylemi iki nokta arası karşılaştırmaları ile belirlenen tercihlerin fonksiyonu olarak görürler. Yeni duruma uyum sağlamanın faydaları ve maliyetlerinin değerlendirilmesi sürecini yönlendiren aktörler ve çıkarlarıdır. Aktörler, geçmiş düzenlemelerdeki mevcut avantajlı konumlarını ve yatırımlarını korumak için veya aktörlerin yüklendiği maliyetleri azaltmak için hâlihazırdaki mevcut durumu dönüştürürken, yeni kurulacak düzenin dengeleyicisidirler. Böylece geçmiş kararlar, dönüşümün muhtevasını şekillendirir. Tarihsel kurumsalcı çalışmaların odak noktası, hangi geçmiş kararlar ve modellerin, aktörlerin, kurumların güncel ve olası gelecekteki yapıları üzerindeki tercihlerini şekillendirmedeki anahtar tanımlayıcı faktör olduğudur. (Pierson 2004; Thelen 2004)

Rasyonel seçim geleneğinde iki olası alternatif aday arasında tercih yaparken, örtük bedeller (sunk costs), miras etkileri (legacy effects) gibi faktörler etkisizdir ve dikkate alınmaz. Tarihsel kurumsalc1lıta ise tersine, karar tercihini şekillendiren, tarihsel bir referans noktasından ölçülen değişimin derecesidir. Bu değişiklikler aktörlerin avantajlı konum edinmeleri ya da bu konumlarını korumalarının derecesini belirler. Geçmiş modellerle ilişkili olan ve bu modellerde öncelikli bir konum edinmiş olanlar, kendilerine uzun vadede artan getiriler, olumlu çıktılar ve diğer faydalar sağlayacak, kurumlarda kalıcı nüfuz sahibi olacakları bir modele doğru dönüşümü desteklerler.

Rasyonel seçim modelindeki, oransal açıdan daha iyi olan alternatifin mutlaka tercih edileceği varsayımına karşılık tarihsel kurumsalcı gelenekte bu dönüşüm tercihi, ancak gelecek modeller, geçmiş yapıyla bağların koparılmasından doğan kayıpları telafi edecek cinsten ise gerçekleşir. Çünkü bu koşullu şartlanmış kuramsal bağlamdaki kayıpların doğası, aynı dışsal parametrelere maruz kalacak biçimde konumlanmış aktörler üzerinde farklı tepkiler üretmektedir. Burada önemli bir nokta şudur ki; 
büyük krizler gibi dışsal gelişmeler, tarihsel kurumları çok önemsemeyen bazı ülkelerdeki gruplar üzerinde ulusal modelleri dönüştürecek tercihleri harekete geçirirken, aynı olaylar tarihsel kurumları dikkate alan başka ülkelerde hâlihazırdaki modelleri güçlendirecek tercihlere hizmet edebilir. (Falletti ve Lynch 2009)

Tarihsel kurumsalcılık sıklıkla delikli denge modelleriyle ilişkili görülse de bu modellerin savunucuları geleneğin içinden bazı akademisyenler tarafindan, tercihlerin evriminin içsel süreçlerini göz ardı ettikleri gerekçesiyle eleştirilere maruz kalmışlardır. (Capoccia ve Kelemen 2007)

Sosyolojik kurumsalc1lar gibi tarihsel kurumsalcılar da öğrenmenin, inançlara ikna olmanın ve sosyal süreçlerin kurumsal modeller üzerindeki tercihleri şekillendirmede önemli bir rol oynadığını kabul etmektedirler, fakat tarihsel kurumsalcılar uluslararası örgütler gibi sosyal kolektiflerin, yerel grupların kimlik ve tercihlerini şekillendirmede daha küçük bir rolü olduğunu düşünmektedirler. Tarihsel kurumsalc1lar genelde sosyolojik kurumsalc1lar tarafindan benimsenen, ortak anlayışların yeni kurumların kaynağı olduğu fikrini tersine çevirerek, belirli kurumların varlığının yeni fikir ve anlayışların önemli olup olmayacağına dair karar vermede rol oynadığını düşünürler. Bu sebeple, onların fikirlerin rolüne dair çalışmaları, politik sonuçlara yol açabilen kurumlarda içselleştirilmiş fikirlerin durumuna odaklıdır. Bu bağlamda ilkesel inançlardan çok, siyasal paradigma oluşturan fikirlere önem verirler. (Goldstein 1993; Hall 1993; McNamara 1998; Blyth 2001)
Tarihsel kurumsalcılığın, sıklıkla uluslararası ilişkiler içerisinde ayrı ve köklü bir yeri olan tarihsel sosyolojiyle ilişkilendirilen makrotarihsel çalışmalardan farklı olmasının en büyük nedeni metodolojik bireyciliğin benimsenmesidir. (Hobden ve Hobson 2002; Lawson 2006) Örneğin, tarihsel sosyolojinin kritik tarihsel kavşaklardan sonraki sürekliliği açıklarken önceki yapısal koşulları vurgulama eğiliminde olmasının aksine tarihsel kurumsalcılık, aktörler için böylesi kavşaklar sırasında veya sonrasında yeniden üretim ve tersine dair dürtüleri yaratan mikro-seviye süreçlerin önemine vurgu yapmaktadır. (Capoccia ve Kelemen 2007) Tarihsel kurumsalcılık aynı zamanda, birçok tarihsel sosyoloji çalışmasının merkezindeki geniş yapısal dönüşüm tiplerinden ziyade, politik aktörlerin davranışlarının, kademeli değişimin farklı formlarını nasıl şekillendirdiğine daha çok odaklanmaya meyillidir. (Streeck ve Thelen 2005; Mahoney ve Thelen 2009)

Tarihsel kurumsalcıların kurumsal değişim modellerine dair açıklamalarında tercihlerin yapısı ve kökenini anlamak merkezi bir önem arz etmektedir. Çünkü geçmiş modellerdeki yatırımlar, bireyler yeni gerçekliklerle ve kademeli reform yahut kökten dönüşüm kararı gerektiren durumlarla karşılaştıklarında, tercihin hangi yönde olacağını belirleyecektir. Tarihsel kurumsalcılar, uluslararası ilişkilerde rasyonel seçim modellerinde büyük önem atfedilen tarihsel etkililik kavramının geçerliliğine dair şüpheci bir görüşe sahiptirler. (March ve Olsen 1984) Rasyonel Seçim kurumsalcılığı tarihi, örtük bedelleri dikkate almadan etkili görür oysa tarihsel kurumsalc1lar, bu bedellerin ve miras 
etkilerinin, tasarımların evrimini şekillendirmede anahtar faktör olduğunu belirtmektedirler. Buna ek olarak örneğin tarihsel kurumsalcılar, çıkar gruplarının bulundukları avantajlı konumu, bir kurumun kuruluş anındaki stratejik pozisyonların işgal edilmesine borçlu olduklarını vurgulamaktadırlar. Yahut farklı olumlu çıktıları olan bir alternatif ile karşılaştıkları zaman çıkar gruplarının radikal değişim yerine, mevcut düzenlemelerin yeniden uyumlanmasını tercih ettiklerini söylemektedirler. Sonuçta, öncelikli pozisyonlar ve iş bölümü üzerindeki göreceli güç değişimi dengesi sağlandığında, büyük kolektif etki yaratacak uyumlama modelleri ortaya çıkmaz ve kurumlar sıklıkla orijinal ayarlarını korumuş olarak varlıklarını sürdürür. (Pierson 2004 ve Thelen 1999).

\section{Tarihsel Kurumsalcı Geleneğin}

\section{Anahtar Kavramları}

Tarihsel etkisizlik (historical inefficiency), yaygin olarak tarihsel kurumsalc1lıkla ilişkilendirilen yol bağımlılığı kavramının merkezindedir. Yol bağımlılı̆̆ (path dependence), s1klıkla kritik bir kavşak konumunda olan belirli anlardan sonra kurulan hâkim yapıdaki süreçlere atıfta bulunur. Bu belirli anlar, yeni tesis edilecek model karşısında daha etkili alternatif kurumsal modellerin zafer kazanma ihtimalini azaltacak gelecekteki rotayı şekillendirir. (Pierson 2004, s.17)

Tarihsel kurumsalcı geleneğin erken çalışmalarında yol bağımlılığı, kurumsal gelişmelerde belirlenimci bir anlayışı getirdiği gerekçesiyle eleştirilmiştir. (Crouch ve Farrell 2004) Güncel çalışmalarda ise gelenek, yol bağımlı rotaları güçlendiren veya baltalayan mikro-seviye mekanizmaların açıklanması konusuna ağırlık vermektedir. (Pierson 2004; Thelen 1999 ve 2004)

Güncel çalışmalar, gelişmelerin neden belirli ve sağlam bir yol üzerinde ilerlediğine dair dört sebebe büyük önem atfetmektedir. Kurumlar uzun süreli zaman dilimleri içerisinde güç dengelerine ve politika paradigmalarına bağlı kalabilirler. Ayrıca mevcut modelleri korumak, çıkar sahipleri için, çoğunlukçu bir tercih olmasa da en önemli çıkarlarını içeren ayrıcalıklı pozisyonlarını sürdürmenin aracı olarak görülebilir. Böylesi durumlarda yeni bir düzenlemeyi devreye sokabilme ihtimali ancak kurum üzerinde nüfuzu en yüksek olan aktörlerin mutabakata varmasıyla ortaya çıkabilir.

Eğer bağlılık etkileri (lock-in effects) mevcut ise en iyi olmayan modeller uzun süreli zamanlar boyunca yürürlükte kalabilir, çünkü bir kere benimsenmiş olan kurallar çıkar gruplarına köklü değişiklikleri önleme gücü vermektedir. Tarihsel kurumsalcılı̆̆ın erken çalışmaları, rasyonel seçim ve sosyolojik kurumsalcı çalışmalarda da görülen bağl1lık etkilerine odaklıydı fakat güncel çalışmalarda belli bir yol bağımlılığı üreten diğer üç mekanizma daha fazla önem kazanmıştır. Zamanla kurumlar yeni çıkar grupları yaratabilirler ya da mevcut seçmenlerin olumlu geribildirim etkilerine (positive-feedback effects) bağlı olarak hâlihazırda yürürlükte olan düzenlemeyi desteklemelerine sebep olabilirler. Bu olumlu geribildirim etkileri aktörlerin ağ ve koordinasyon etkisi yaratmasiyla var olurlar. Artan getiriler (increasing returns), olumlu geribildirim etkilerine benzer 
ama bunlar belirli bir modeli devreye sokmaktan kaynaklanan basit küçük kazanımlar değil, bir kere gerçekleşebilen alternatiflerle ilişkili getirilerdeki istikrarlı artıştır. (Page 2006, s.88) Son olarak kurumlar, diğer kurumlarla tamamlayıcı ilişkiler yaratabildikleri ölçüde kendi kendini destekleyen (self-reinforcing) bir yapıya sahip olabilir. Son üç nedende, bir kez benimsenmiş olan modeller, yeni ve mevcut seçmenler üzerinde kökten değişikliğe nazaran kademeli değişikliği desteklemek yönünde yoğun bir destek yaratır ve modelin devamlılık potansiyelini güçlendirir. (Pierson 1993)

Genel olarak bu dört faktörden herhangi biri mevcutsa tarihsel kurumsalcılar, kurumsal gelişim modellerinin rasyonel seçim ve sosyolojik kurumsalcılığın öngördüğünden daha seyrek, yavaş ve kademeli olmasını beklerler. $\mathrm{Bu}$ faktörlerin aynı anda var olma ihtimalinin artışıyla doğru orantılı olarak zaman içerisinde radikal kurumsal değişim beklentisi de azalmaktadır. (Mahoney, Kimball ve Koivu 2009) Zaman içerisinde yol bağımlıı̆̆ı̆ı besleyen bu dört faktörden, üç varsayım ortaya çıkmaktadır. Birincisi; kurumlardaki değişiklikler ve politikada büyük dönüşlerin yaşanma ihtimali, bu dört faktörden herhangi birisi ya da özellikle birkaç tanesi aynı anda mevcutsa daha düşük olacaktır. İkincisi; zaman içerisinde çıkar gruplarının bazı kurumsal gelişmelerden sağladığı faydalardan ötürü, bir düzenlemenin orijinal isteklendirmesinden sapılmış olsa bile kurumsal istikrar devam edecektir. Son olarak; mevcut modellerden ileri gelen avantajların tadını çıkaran aktörler, somut faydaların kaynağı konumundaki kurumsal fonksiyonları etkilemeyecek yeni kurumlar ve politikalarla işbirliğini tercih edeceklerdir. Tam tersini düşünürsek, bu dört faktörün yokluğunda, özellikle olumlu geribildirim etkisi yoksa veya seçmenler artan getirilerden yararlanamıyorsa kurumlar radikal değişimlere daha duyarlı olacak demektir.

\section{Tarihsel Kurumsalcı Literatürden}

\section{Örnekler}

Tarihsel kurumsalcı çoğu çalışma uluslararası ilişkilerde yol bağımlılığını besleyen nedenleri operasyonelleştirmiş ve aralarındaki ayrımları ortaya koymuştur. Büyük bir istisna, uluslararası ilişkilerde kendini tarihsel kurumsalcı olarak tanımlayan ilk kitap olan Ikenberry'nin “Zaferden Sonra"sıdır. (Ikenberry 2001) Ikenberry, bu eserinde devletlerin uluslararası politika kurallarını inşa ederken güç asimetrileriyle nasıl başa çıktıklarını sorgular. Savaşların ardından devletler, hegemonik güçlerin dayattığı kurallara dayalı bir sistemi işletmek, kendi aralarındaki güç dengesini tesis etmek ya da hukuk kurallarına dayalı yasal bir düzeni hayata geçirmek suretiyle istikrarı artırabilirler. Ikenberry, Napolyon Savaşları, İki Dünya Savaşı ve Soğuk Savaş sonrası düzenlemelerin ve bunların kurumsal karakterinin önemli ölçüde değişmesinin, büyük güçler ve ikincil devletler arasındaki pazarlıkların muhtevasını belirleyen bir özellik olduğunu söylemektedir. Devletler yasal düzenlemeleri artan bir şekilde önemsemişler ve kurala dayalı yönetişimin seviyesi zaman içerisinde kapsamını geliştirmiştir. Ikenberry'nin güncel sisteme dair görüşü, ne çok taraflılığın diğer alternatiflerinden daha uygun olduğuna inanan ABD politika yapıcılarının aydınlanmış liderlik iddialarına ne de geçiciliği 
tartışılmayan hegemonik bir ABD fikrine dayanır. O, Soğuk Savaş sonrası yeni düzenin inşasının, eski modellerle ilişkili örtük bedeller ve artan getiriler tarafından kısıtlandığını savunmaktadır. Ikenberry, ABD dış politikasında liberal uluslararasıcılık fikirlerinin rolü olduğunu kabul ederken, en önemli belirleyici olarak siyasi hiziplerin menfaatlerini gösterir. Tercihlerin kademeli dönüşümüne ve erken ikinci dünya savaş1 sonrası dönemde tesis edilen modelde geçmiş düzenlemelerin çıkar gruplarını nasıl yarattığına işaret eder. Ikenberry, büyük tarihsel kavşaklara rağmen kurumsal devamlılığın yüksek seviyede olmasına katkıda bulunan mikroseviye mekanizmalara da dikkat çekmiştir. Bu sayede Soğuk Savaş sona erdiğinde çok taraflı düzenin de dağılacağını düşünenlerin neden yanıldıkları (Mearsheimer 1990) ve 11 Eylül 2001 sonras1 uluslararası sistemin özünün neden oldukça dirençli kaldığı (Ikenberry 2009) gibi önemli soruların cevaplanabilmesine yardımcı olmuştur.

Soğuk Savaş'ın sona ermesinden sonra NATO gibi uluslararası organizasyonların sürekliliğine dair çalışmalar da orijinal kuruluş isteklendirmesinin artık mevcut olmadığ $\mathrm{du}$ rumda devletlerin bu örgütleri kademeli şekilde yeniden yapılandırarak sürdürmesindeki kazançlarının kurumsal düzleme yansımalarını vurgulamaktadır. (Wallander 2000) Ayrıca Borton, Golstein, Josling ve Steinberg'in eseri “Ticaret Rejiminin Evrimi”, erken savaş sonrası dönemde uluslararası kurumlardaki çok taraflılığın artırılması çabaları için yerel seçmenlerin desteğinin nasıl arttığına dikkat çekiyor. Barton ve arkadaşları tarihsel kurumsalcı araştırma programının merkezinde, hem süreçlerdeki yavaş değişim periyotlarının hem de çok taraflı11ğın kapsamındaki istikrarlı genişlemenin altında yatan mantığın olduğunu düşünmektedirler. Önce gelen çok taraflı anlaşmalar, serbest ticaretin genişlemesine ve güçlenmesine sebep olmuş ve yerel seçmenlerin desteğini, olumlu geri bildirim etkileri aracıllğıyla kazanmıştır. Böylece büyük ticaret devletleri zaman içerisinde daha büyük çok taraflı anlaşmaları desteklemişler ve hâlihazırdaki model meydana gelmiştir. Olumlu geri bildirim etkilerinin ivme kaynağı olmuştur. Ayrıca burada çok taraflı11ğın yavaş yayılmasının ve ticaret anlaşmalarının azalmasının büyük devletler arasındaki düzenleme anlaşmazlıklarından kaynaklandığını vurgulamışlardır. Bu tip düzenleyici uyuşmazlıklar, Barton ve arkadaşlarının tartıştığı biçimde olumlu geri bildirim etkilerinin ürünüdürler. Ancak, ulusal ve sektörel alanda bu etkilerin tezahürleri belirgin olduğu için hükümetler uluslararası pazar serbestîsini artıracak anlaşmalara ulaşmada güçlük yaşarlar. Bu sebeple ticaret anlaşmaları liberal doğrultuda hızla ilerlerken, ulusal düzenleyici sistemlerdeki tarihsel çeşitlilikler, devletlerin yavaş ve doğrusal olmaktan uzak bir yörünge izlemesine sebebiyet vermiştir.

Raustiala'nın "Yasa, Bayrağı Takip Eder mi?" adlı eseri de uluslararası ilişkilerin doğasını şekillendirmede yerel ve uluslararası düzenleyici politikalar arasındaki ilişkiye vurgu yapmaktadır. Modern ulus devletin gelişimi üzerine yapılan zengin ve tarih odaklı çalışmalar genelde ticaret ve savaş üzerine odaklanmış- 
tır. (Tilly 1990; Spruyt 1994; Philpott 2001) Raustiala, modern devlet sisteminin gelişiminde yerel ve uluslararası yasal çeşitliliğe büyük önem atfederek literatüre bu yönde bir katkıda bulunmaktadır. Raustiala, yerel ve yasal düzenleyici geleneğin ve hukuksal, yönetimsel ve ticari çıkarların korunması için ABD tarafından atılan adımları önemsemekte ve dikkat çekmektedir. Onun değerlendirmesine göre bu gibi ç1karlar yerel gelişmelerin ürünüdür ama hükümetlerin bu çıkarları koruma kabiliyeti dışsal olaylarla koşulludur.

Diğer tüm siyasal alanlarda olduğu gibi istenmeyen sonuçlara (unintended consequences) dair çalışmalarda da, tarihsel etkisizlik ve yol bağımlılığını destekleyen faktörler merkezi role sahiptir. (Jervis 1997) Beklenmeyen sonuçlar üreten kurumsal yapılar, tipik olarak kuruluş anlarındaki gücü şekillendiren bilişsel sınırlamalar veya daha sonra ortaya çıkan karmaşık etkileşim etkileriyle bağlantılıdır. (Keohane 1984; Barnett ve Finnmore 2004) Tarihsel kurumsalc1lar tüm bu faktörleri kabul ederken, istenmeyen sonuçların aynı zamanda eksiksiz bilgi sahibi devletlerin şeffaf hareket ettiği ve büyük zamansal sınırlamalarla karşılaşmadığı durumlarda da belirgin bir bulgu olduğunu görmüşlerdir. (Lindner ve Rittberger 2003) Buna ek olarak tarihsel kurumsalcılar istenmeyen sonuçların kaçınılmaz olabileceğini düşünen diğer gelenekler içindeki akademisyenlerle bu konuda hemfikirken zaman içerisinde yeniden üretilmeleri sıklıkla, az da olsa kaçınılabilirlik olduğunu belirtirler. Onlar modellerin türetimi, bağl1lık etkilerinden -özellikle olumsuz sonuç- ları olan- daha fazla olduğunda bunun açıklanmaya değer bir politik eylem olduğunu vurgularlar.

Tarihsel kurumsalcılar kuruluş anlarında bilgi yeterli seviyede olmasına rağmen istenmeyen sonuçların ısrarla var olmasına neden olan birçok başka sebebe de vurgu yaparlar. Örneğin bir organizasyonun kuruluş anında kendini kanıtlayan etkili karakteri daha sonraki aşamalarda karşılaşılan güçlüklerin doğasından ötürü etkililiğini ortaya koyamayacak bir şekle bürünebilir.

Borton, Goldstein, Jasling ve Steinberg, 1947'de Gümrük Tarifeleri ve Ticaret Anlaşması'nın imzalanmasıyla kurulan düzenin zaman içerisinde bazı taraf ve taraf olmak isteyen devletler için birtakım olumsuz ve istenmeyen sonuçlar ortaya çıkardığını bulmuşlardır. Çünkü bu anlaşma, uluslararası ticaretin gelişimini cesaretlendirmek için tercihe bağlı ticaret anlaşmalarının tesis edilmesine olanak sağlarken aslinda ticaret rejiminin temel elementi olan en çok gözetilen ulus ilkesinin altının oyulmasına sebep olmuştur. Bir yandan sınırlaması çok zor bu tip süreçler yaşanırken diğer yanda devletlerdeki ekonomik gruplar, böyle anlaşmalarla avantajlar elde etmişler ve bu avantajların devamlılığ için geniş yatırımlar yapmışlardır. Bu durum, tam manasıyla çok taraflı bir ticaret rejiminin inşa edilmesini ve kapsamının genişlemesini yavaşlatmıştır.

Paradoksal olarak 1995 Dünya Ticaret Örgütü Anlaşması ekonomik ayrımcılığın var olan türlerini azaltmış olsa da bazı üye devletler için istenmeyen sonuçlar üretmiştir. Özellikle 
gelişmekte olan ülkelerin, zenginliği elinde tu$\tan$ ülkeler karşısındaki kabiliyetini yükseltmeyi amaçlayan modeller, çıkarlarını siyasal süreçler yoluyla korumaya muktedir ve bol kaynaklardan faydalanma kapasitesi yüksek ülkeler sebebiyle tersine etki oluşturmuştur. (Shaffer 2006)

İstenmeyen sonuçlar her yerde bulunabilir olmasına rağmen bunların ne zaman meydana geldiği ya da olumlu mu yoksa olumsuz mu olduğu olduğuna dair genelleştirilebilir ifadelerde bulunmak zordur. İstenmeyen sonuçları tanımlamak, bağımlı değişkenin seçilmesini içerir. Sadece ortaya çıktıklarında gözlenebilirler. Yoklukları durumunda tam manasiyla tanımlanamazlar. Ancak tarihin akışı içerisindeki materyaller olmaları bu çıktıları incelemek için iyi bir nedendir. Bu bağlamda tarihsel kurumsalcılar, belirli istenmeyen sonuçların tahmin edilebilir olsalar da olmasalar da neden etkili olduğuna dair önemli katkılar yapmışlardır. Bu türde çıktıların açıklanması için güncel çalışmalar, tesadüfî olaylar, bilişsel sınırlamalar ya da bürokratik patolojilerin, karmaşık karşılıklı etkileşim etkisi ve uluslararası modeller üzerindeki gelişmelerin ne gibi tercihler ve sınırlamalar ortaya çıkardığının incelenmesinin dikkatli bir analizi için olmazsa olmaz olduğunu önermektedir.

Zamanlamanın rolünün gelecek yörüngeleri şekillendirmedeki etkisine ek olarak tarihsel kurumsalcılar, politik olaylardaki stralamanın rolünün (role of sequence) takip eden değişikliklerde ne derece önemli bir etki yaratabileceğinin altını çizerler. Alternatif fikirler bü- yük bir destek kazanmadan önce organizasyonel yapılar içerisine gömülü fikirler, bazen diğer fikirler daha meşru gözükmesine rağmen korunmaktadır. Örneğin; politika yapıcıların ekonomilerini, küresel ekonomiye entegre etmeleri, uzak bir gelecekte olası artan güvenlik tehdidine rağmen nükleer silah ediniminin reddedilmesine vesile olabilmektedir (Solingen 2007) veya bir yönetim, siyasal kurumlar üzerinde hukukun üstünlüğü ve özgür basın gibi demokratikleşme düzenlemelerine giriştiğinde bu durum söz konusu devletin savaş eğilimini de kalıcı bir biçimde azaltıcı sonuçlar üretebilmektedir. (Mansfield ve Snyder 2005)

Newman'ın "Gizliliğin Koruyucuları" ve Abdelal'ın “Sermaye Kuralları”nda tarihsel sıralamanın ampirik bulmacaların çözülmesine nasıl yardım ettiği hususu belirgindir. İki ça1ışma da benzer bir konuyu inceler: "Avrupa ülkeleri, askeri ve ekonomik açıdan ABD'ye nazaran çok daha zayıf olmalarına rağmen küresel düzenleyici yapılarda nasıl bu kadar etkili olabilmektedir?" Veri gizliliği ve finansal düzenlemelere odaklı iki eserde, Avrupa'nın, etkinliğini 1970 ve 1980’lerde kilit Avrupa ülkelerinin bu alanlardaki işbirliğini derinleştiren yerel politik süreçlere borçlu oldukları sonucuna ulaşılmıştir. (Newman 2008; Abdelal 2007) Newman ve Abdelal, ilerleyen süreçte ABD muhalefetine rağmen Avrupa ülkelerinin, dijital ve finansal alanda uluslararası organizasyonlarda stratejik pozisyonlar elde ederek, uluslararası düzenlemeleri şekillendirmedeki nüfuzunu arttırmas1nın ve ABD'nin tartışmasız hegemon olarak görüldüğü 1990’larda bile tek taraflı düzenleme- 
leri uygulamaya sokmasının nasıl önüne geçildiği konularında tarihsel sıralamanın rolüne vurgu yapmaktadırlar. Çalışmalardan çıkarılabilecek bir başka sonuç ise Avrupa'nın potansiyel olarak kendisinden daha büyük ekonomiye sahip bir ülke olarak Çin'e göre uzun vadede nüfuz sahibi olduğu düzenlemelerin avantajlarını yaşayacak olması ve bunlar üzerindeki etkililiğini daha güçlü bir şekilde devam ettireceğidir.

Olayların sıralaması, sadece kronolojik açıdan değil, hangi olayların politik aktörlerin çıkarlarını ne şekilde etkilediğini, sonuçları şekillendirme yeteneklerini ve tarihin akışını yönlendirebilmelerini göstermesi açısından dikkate değerdir. $\mathrm{Bu}$ sebeple tarihsel kurumsalcılar olayların, daha önceki olayları şekillendiren çıkarlar, güncel ve gelecek politik çatışmaların bağlamı dikkate alınmadan yalıtılmasını doğru bulmazlar. Başka bir deyişle sıralamayı dikkate almak, gerekli ve yeterli şartlar oluştuğunda özel türde sonuçların mevcudiyetinin varlığına ve tarihin ne zaman ve nasıl önem arz ettiğine dair cevaplar sağlayabilir.

\section{Tarihsel Kurumsalcı Çalışmalarda}

\section{Öne Çıkan Gündemler}

Tarihsel kurumsalcılık için merkezi olan kavramlar tikel olaylar ve genel yapilar arasında bir denge (balance) gözeterek uluslararası ilişkilerdeki güç ve egemenliğe dair özel olaylar üzerinden açıklamalar sunmaya çalışır. $\mathrm{Bu}$ geleneği diğer iki kurumsalcı gelenekten ayıran en temel husus, ampirik bulmacaların çözümünde mikro-mekanizmaların belirleyici olması ve ikinci-derece farklılıkları oluşturmas1dir.
Uluslararası ilişkilerin tarihle önceki ilişkilerinin aksine, tarihsel kurumsalcılık geçmişin bir dökümantasyonunu yapmaktan çok belirli mekanizmaların etkisi altında, geçmiş etkilerin bugünü ve geleceği nasıl şekillendireceğiyle ilgilenmektedir. Her ne kadar tarihsel kurumsalcılığın asli teması ve merkezi kavramları uluslararası ilişkiler çalışmalarına yapıcı katkılar sunmuş olsa da bu geleneğin geleceği güncel araştırma gündemine sunacağı başarılı katkıların ölçüsünce tayin edilecektir. Uluslararası ilişkilerde bir araştırma alanı olarak güncel uluslararası kurumlarda devamlılık ve değişimin doğası artan bir önem kazanmıştır. Keohane'in belirttiği gibi "Benzeri görülmemiş değişimlerin yaşandığı bir dönemde yaşıyoruz. Değişim anlayışımız, uzun dönemli düzenlemelere dair anlayışımıza kıyasla çok alt seviyede.” (Keohane 2008, s. 710)

Değişimi ele alan çalışmalara tarihsel kurumsalc1 geleneğin yapacağı katkı değerlendirilirken mikro-seviye devlet tercihleri (microlevel state preferences), yönetişim boşlukları (governance gaps) ve uluslararası sistemde kurumsal gelişimin genel yapısını anlamak gerekmektedir.

Uluslararası örgütler ve hükümetdışı organlar dünya siyasetinde belirgin bir otonomi ve etkinlik kazansalar da (Barnett ve Finnmore 2004; Ruggie 2004) hala uluslararası kurumlar1 önemli ölçüde şekillendiren anahtar aktörün devletler olduğu yönünde yaygın bir kanaat vardır. Sonuç olarak bir devletin dış politikasını nelerin şekillendirdiği ve özel olarak belirli ulus- 
lararası kurumları desteklerken neyi amaçladıkları hala uluslararası ilişkilerin büyük sorunlarindandir.

Uluslararası ilişkilerdeki kurumsal dönüş, disiplini devletlere göreceli belirsiz birimler olarak yaklaşmaktan ziyade onları devlet tercihlerinin kökeni, evrimi ve çeşitliliği merkezinde sabit tercihleri olan birimler olarak ele almaya doğru itmiştir. (Frieden 1999; Moravscik 1997) Gitgide daha çok çalışma, hükümetlerin çok taraflı tercihlerini şekillendiren yerel süreçlere odaklanmıştır. Devlet tercihlerini incelerken, yerel gruplar ve kamu görevlilerinin hükümet politikalarını şekillendiren kilit aktörler olarak ele alınmasıyla karakterize olan çoğulcu politika modelleri, yaklaşımın disipline yaptığ 1 katkının altında yatan bir başka öğedir.

Uzun dönemli kurumların, toplumsal tercihlerin bütününü nasıl etkilediğinin altının çizilmesinin ötesinde tarihsel kurumsalc1lık aynı zamanda tarihsel koşullu ulusal yapılanmaların, yerel grupların çıkarlarını nasıl şekillendirdiğine ve hükümetlerin pozisyonlarını uluslararası düzenlemelere nasıl adapte ettiğine dikkat çekmektedir.

Tarihsel kurumsalcılar, grupların kurumsal tercihlerinin yapısının, önemli ölçüde hâlihazırda var olan ve özellikle artan getiriler ve olumlu çıktıların kaynağı olan geçmiş modellerdeki yatırımlar tarafından şekillendirildiğini varsayarlar. (Farrell ve Newman 2010) Diğer kurumsalc1 geleneklerin temsilcilerine nazaran tarihsel kurumsalcilar, devletlerin ulusal politikaları ve kurumsal seçimlerinde yeni uluslararası kural ve normların etkinliğine daha şüp- heci yaklaşırlar. Bu noktada tarihsel kurumsalc1lığın ürettiği hipotezlerin test edilmesinde Avrupa Birliği önemli bir uluslararası organizasyondur. Çünkü üye ülkeler için benzer dışsal s1nırlamalar söz konusudur. (Meunier ve McNamara 2007; Pierson 1996) Örneğin, ekonomik küreselleşmeye ulusal tepkileri ele alan tarihsel kurumsalcılıkla ilgili çalışmalar, kapitalizmin ulusal çeşitliliğindeki farkların, hükümetlerin neden uluslararası işbirliğinin farklı formlarını desteklediklerini göstermede anahtar role sahip olduklarını ortaya koymuştur. $\mathrm{Bu}$ çalışmalar, ekonomik grupların maddi profilini ve hükümetlerdeki yerel çıkar gruplarını besleyen kurumsal avantajların, olumlu çıktıların ve artan getirilerin kaynağı olan hâlihazırdaki ulusal modelle koşullanmış farklı çok taraflı modellerin desteklenmesine bağlı olarak meydana gelen devlet tercihlerinden kaynaklı bir politik ekonomi yaklaşımının ortaya konulmasını sağlamıştır. (Callaghan ve Höpner 2005) Diğer öğelerin yanı sıra bu çalışmalar, hükümet değişikliklerinin partizan doğasına sahip belirli devletlerin tesis ettiği modellerdeki kayda değer sürekliliğin ve zaman içerisinde devletlerin yapısı üzerindeki kalıcı değişimlerin neden var olduğunu açıklamaya yardımcı olmuşlardır. Gilpin, yerel ekonomilerin ve bu ekonomilerdeki farklılıkların rolünün uluslararası ekonomik meselelerde belirgin bir şekilde tayin edici hale geldiklerini belirtmektedir. (Gilpin 2001, s.148) Ancak uluslararası ilişkiler alanı, ulusal ekonomik sistemlerin evriminin uluslararası kurumları şekillendirmedeki rolüne dair henüz ön hazırlık aşamasında bir anlayışa sahiptir. (Keohane 2008, s. 711) 
AB'ye dair tarihsel kurumsalcı çalışmalar, uluslararası işbirliği formlarının ulusal modellerle ilişkili avantajlara sahip yerel seçmenlerin yatırımlarını nasıl etkilediğine dair açıklamaların eksikliğini kapatmak üzere yola çıkmışlardır. (Farrell ve Newman 2010) Böyle bir yaklaşımı çeşitli hipotezler takip eder. Örneğin, yerel grupların karşılaştırmalı avantajlarının kaynağı olan ulusal modellerle olan ilişkisi, bu grupların yerel kurumlarla bütünlügünü koruyacak uluslararası modellere destek vermelerine sebep olmaktadır. (Pierson 2004, s. 153) Yerel gruplarla uluslararası anlaşmalar ve yasal düzenlemeler arasındaki uyum arttıkça, tarihsel yatırımların etkisiz kalacağı yeni alanlar ve modellerin hükümetler tarafindan desteklenme ihtimali de azalmaktadır.

Tarihsel kurumsalcılar, hükümetlerüstü işbirliğinin yoğun formlarının ulusal seviyede benzer düzenlemeler yaratacağı konusunda şüphecidirler. Ulusal düzenleme sistemlerinin parçalanmış veya merkeziyetçi olması gibi tarihsel koşullu meseleler, çıkar gruplarının politika yapımı süreçlerindeki kabiliyetlerini doğrudan etkilemektedir ve çeşitli kurumların hızlı ve başarılı bir şekilde anlaşabilmelerini sağlamakta ya da tersine sebep olmaktadır. (Singer 2007) Buna ek olarak tarihsel kurumsalcılar, uluslararası işbirliğinin yeni formlarındaki artışın ulusal modelleri temelden değiştirmesini beklemezler. Aslında, Avrupa Birliği ve G20'de artan bir şekilde gözlenen işbirliği türünün evrimi sürecini, uluslararası anlaşmalar karşısında devletlerin içinde bulunduğu tarihsel çeşitliliğe göre şekil alan düzenlemenin ulusal formlarında karşılaşılan zorlukların tezahürü olarak değerlendirirler.

Tarihsel kurumsalcılığın devlet tercihlerine atfettiği önem, uygunluk ve sonuç mantığına güçlü vurgu yapan yaklaşımlardan daha fazladır. Tarihsel kurumsalcılık devletlerin uluslararası kurumlar ile nasıl bütünleştiği, hangi koşullar altında uzlaşma sağlanabildiği ve devletlerin uluslararası yapıları zaman içerisinde neden sahiplendiği veya reddettiği gibi meselelerle ilgili tatmin edici seviyede ve çeşitlilikte teorik argümana sahiptir. Bu yaklaşım aynı zamanda devletlerin uluslararası güçlükler karşısında neden farklı tepkiler ürettikleri ve uluslararası kurumların yapısına dair görüşlerinde neden ve ne zaman devaml1lı gösterdikleri ile ilgili ayrıntılı ve kapsamlı açıklamalar sağlamaktadır.

Erken 21. yüzy1lda uluslararası sistem yönetişim paradoksu ile karakterize olmuştur. Uluslararası meseleleri yöneten organizasyonlar hiç olmadığı kadar fazlalaşmış, kaynaklar ve yetkilerle donatılmıştır. Buna rağmen yine aynı organizasyonlar, tarihin hiçbir döneminde olmadığı kadar beklentileri karşılama noktasında yetersiz kalmakta ve bu yüzden ağır bir biçimde eleştirilmektedir. Tarihsel kurumsalcı gelenekte bu paradoks, çeşitli yönetişim boşluklarının ortaya çıkışı ve sürekli var oluşu ile açıklanır. Yönetişim boşlukları, bir organizasyonun hedeflediği ve gerçekte sundukları arasındaki farktan kaynaklanan uzun dönemli tutarsızlıklar ve yaygın bir şekilde ihtiyaçları karşılayan bir modelin olmadiğı durumlardan doğan olaylara işaret eder. 
Tarihsel kurumsalc1lık politika yapıc1ların bilişsel sınırlılıklarını ve sosyalleşme etkilerini kabul ederken, temsilcileri bu tip boşlukların diğer kurumsal geleneklerde olduğu gibi kolayca kapanabileceğine ya da ilk önce kapanacak yönetişim boşluğunun en büyüğü olacağına karşı şüphe ile yaklaşırlar. Yönetişim boşluklarının göreceli olarak devamlılık arz etmesinin ve zamanla sayılarının artmasının iki büyük nedeni vardır. Birincisi; kurucu anlar, belirli devletlerin uluslararası organizasyonlar içerisinde öncelikli bir pozisyon elde etmesini să̆lar ve büyük reformlara dirençli yapılar oluştururlar. Bunun en somut örneklerinden birisi Birleşmiş Milletler Güvenlik Konseyi daimi üyesi İngiltere ve Fransa'nın durumudur. Bu devletler, Almanya, Japonya ve Hindistan gibi kendilerinden ekonomi ve işgücü anlamında daha güçlü ülkeler karşısında, Birleşmiş Milletler Anlaşması'nın 1945 'te belirlediği öncelikli pozisyonlarının avantajlarını hala sürdürmektedirler. 1945'teki kurucu anın etkisi, değişen güç dengelerine rağmen devam etmekte ve bir yönetişim boşluğuna sebep olmaktadır. (Bourantonis 2005, s. 97) Sonuç olarak bu boşluk zaman içerisinde kapanmamakta, tam tersine öncelikli pozisyonları işgal etmiş devletlerce yeni düzenlemeler oluşturulmak suretiyle büyümektedir.

İkincisi; hükümetler ve yerel seçmenlerinin, hâlihazırda var olan düzendeki çıkarları ve yatırımları boşluğun kapanmasına engel olmaktadır. Buna dair dikkate değer örnekler küresel halk sağlığı rejimi ve çevre alanında görülebilir. Örneğin, belirli bir hastalık ile mücadelede kullanılan kaynaklar, ne hastalık yüküne ne de küresel normlara göre dağıtılmaktadır. Kaynakların dağıtımı daha çok bağışçı devletlerin yatırım yaptıkları özel programlara olmaktadır ve bu durum uluslararası arenada hastalıkla mücadelenin hızlı ve etkin bir biçimde yürütülmesini engellemektedir. (Garrett 2007) Benzer süreçler çevre alanında da geçerlidir. Uluslararası toplum, uzun mücadeleler sonucunda ekonomide durağanlığın ağır bedellerini göze alarak iklim değişikliğine karşı kapsayıcı ve uygulanabilir anlaşmalar tesis edebilmiştir. (Victor 2001) Ancak endüstrileşmiş devletlerdeki ekonomik çıkar grupları ve serbest pazar ekonomisiyle bütünleşen ülkelerdeki ekonomik gruplar ve hükümetler, bu alandaki uluslararası düzenlemelere, endüstriyel stratejilerinde gözettikleri avantajları zayıflattığ dirler. Paradoksal olarak böyle dirençler, hükümetlerin yönetişim boşluklarını kabul etmeleri anlamına gelecek uluslararası anlaşmalara sebebiyet vermekte, karşılaşılacak yeni yerel politik bedelleri zaman içerisinde genişletmektedir.

Tarihsel kurumsalcılar, yönetişim boşluklarının asla kapanmayacağı tezini savunmazlar. Bunların hangi ölçüde ulusal düzenlemelere koşullu olduğuna ve uluslararası görüşmeleri karakterize eden kararlara ve kararsızlıklara ne şekilde bağlı olduğuna göre hızlı mı yoksa yavaş mı kapanacağının tayin edileceğini söylerler. Tarihsel kurumsalcılık, yönetişim boşluklarının varlığının sürekli olmasının altında yatan sebebi iklim değişikliğiyle savaşmanın önemi gibi ortak normların eksikliği değil, birbirinden farklı ve çeşitli çıkarlara sahip, kuruluş aşamasında etkinliğe ve özel yatırımlara sahip büyük 
devletler olduğunu söylemektedir. Bu devletlerin bireysel çıkarları gelecekte özellikle kriz anları ortaya çıktığında kolektif zararlara sebep olabilir. Sıklıkla devletlerin yönetişim boşluklarını kapatmadaki başarısızlıkları uyumsuz ulusal çıkarlara yapılan atıf ile açıklanmaktadır. Bu tip açıklamalarda eksik olan kısım, ortak hareket üzerinde geniş bir anlaşmanın faydası ve durağanlığın kolektif bedelleri ortadayken, bu uyumsuz çıkarların neden çeşitlilik arz ettiği ve devletlerin yönetişim boşluklarını kapatmada neden zorlandıklarıdır. Tarihsel kurumsalcılar bu konudaki boşluğu doldurmak için önemli argümanlar sunarlar.

\section{Tarihsel Kurumsalcılığa Göre}

\section{Uluslararası Sistemin Yapısı ve Kademeli Değişim Modelleri}

İkinci Dünya Savaşı’ndan sonra uluslararası sistemin kurumsal karakterinin büyük ve köklü değişiklikler geçirdiğine dair uluslararası ilişkiler disiplini içinde yaygın bir fikir birliği vardır. 21. yüzyılın başlangıcına geldiğimiz süreçte tarihin diğer tüm dönemlerine göre uluslararası kurumların önemi ve kapsamı daha büyüktür. Uluslararası kurumların sayısı, güvenlik, ekonomi, insan hakları, çevre gibi alanlarda gittikçe artmaktadır. Ulusal düzlemden uluslararasına doğru yetki devirleri gerçekleşmekte ve uluslararası organizasyonlar arasında paylaşı1maktadır. (Goldstein vd. 2000; Ruggie 2004; Kahler ve Lake 2003) Ancak uluslararası sistemdeki güncel gelişmeler, egemen otoritenin uluslarüstü yapılara devredildiği, temel sistemsel bir değişiklik anlamına gelmemektedir. (Kahler ve Lake 2009) Buna ek olarak modern uluslararası sistem, diğer iki kurumsalcı gelenekte savunulduğu şekliyle rasyonel olarak veya normatif kurallarla düzenlenmiş de değildir. Uluslararası sistemin durumu daha çok tarihsel kurumsalcıların işaret ettiği şekilde kademeli değişimlerin alternatif türleri arasında var olan bir yapıdadır. Bu gelenek, yeni kurumsal gerçekliği oluşturan temel politik yapının yeniden üretilmesi sürecindeki karmaşık girdileri yaratan kademeli değişim modellerini inceler.

Kademeli değişim modelleri, özellikle yeni tasarımların eskilerinin üzerine eklendiği katmanlama süreçlerini kapsamaktadır. (Streeck ve Thelen 2005; Mahoney ve Thelen 2009) kurumsal katmanlama uluslararası düzende sayısız bağlamda belirgin biçimde gözlenebilir. Devletler, büyüyen uluslararası karşılıklı bağımlılı̆̆ın zorluklarıyla yüzleşmektense hâlihazırda var olan uluslararası organizasyonlardan kaynaklanan çıkarlarından vazgeçmemek adına, alt kurumlar ve yeni kurumsal formlar tesis etmektedir. 1945 sonrasında, bu alt kuruluşların gittikçe artan şekilde gözlenmesi bir vakadir. (Shanks, Jacobson ve Kaplan 1996) Uluslararası sistemdeki bu katmanlaşma sonucu yetkilerini aşan organizasyonlarda düzen karmaşası ortaya çıkmıştır. (Raustiala ve Victor 2004; Alter ve Meunier 2009) Tarihsel kurumsalcilar, özel organizasyonların merkezi kurumlarının farklı hız ve düzeylerde katmanlaşmasının politika yapıcılar için çekici bulunduğundan ötürü gerçekleştiğini vurgulamaktadırlar. (Thelen 1999; Schickler 2001) Katmanlama ile büyük kurumlarda zaman içerisinde radikal değişimler zorlaşmakta ve güç dengesindeki değişimler uluslararası yönetişimin temel dokusuna çok az etki etmektedir. Başka bir deyişle uluslararası 
düzende katmanlama deneyimi en güçlü pozisyonu işgal etmiş ülkelerin konumunu daha da güçlendirmektedir. (Drezner 2009) Katmanlama, kısa dönemde politik olarak etkili sonuç verse de uzun dönemde uluslararası sistemin parçalanmasına, hükümetlerin yeni tasarımlara yatırım yapıp eski modeli korumaktan vazgeçmelerine sebep olabilir. Tarihsel kurumsalc1lar, kademeli değişim modellerinin uygulanması ile oluşan delikli dengenin (punctuated equilibrium) dünya savaşları gibi büyük bir kriz ile karşılaşıncaya kadar geçerli ve etkili olduğunu düşünürler. Streeck ve Thelen'in saptamış oldukları kurumsal değişimin beş modeli şunlardır:

a. Yerdeğiştirme: Bir kurum bir diğerinin yerini alır

b. Kaplama: Bir kurum eski işlevlerin üzerine yeni işlevleri yerleştirir

c. Kayma: Bir kurumun içinde var olduğu ortam değişir ama kurum aynı şekilde uyum sağlayamaz

d. Dönüşme: Kurumlar yeni işlev, hedef ya da amaç benimser

e. Tükenme: Kurumsal çöküş ve başarıs1zlık durumu (Streeck ve Thelen 2005)

\section{Sonuç}

$\mathrm{Bu}$ çalışma tarihsel kurumsalcıllı̆̆ın Uluslararası İlişkiler Disiplini içerisindeki seyrinin alana yapacağı olumlu katkılar aracılığıyla devam edeceğini göstermiştir. Başvurulan literatür örnekleri dahilindeki değişkenler incelenirken açıklanan kavramlar, tarihsel kurumsalcılığın diğer kurumsalcı yaklaşımlardan ve klasik yöntemlerden bağımsız olarak uluslararası ilişkiler çalışmalarında kullanılabileceğini kanıtlamıştır. Tarihsel kurumsalcılığın uluslararası sistemdeki kademeli dönüşümü açıklarken kullandığı kavramlar, bu yaklaşımın sosyal bilimlerde başlı başına münferit bir epistemolojik yaklaşım olarak değerlendirilmesi gerektiğini ortaya koymuştur. 


\section{Kaynakça}

Abdelal, Rawi (2007). Capital Rules: The Construction of Global Finance, Cambridge: Harvard University Press.

Alter, K. J. ve Sophie Meunier (2009). "Symposium: The Politics of International Regime Complexity", Perspectives on Politics, Cilt 7 (1), ss. 1324.

Barnett, Michael ve Martha Finnemore (2004). Rules for the World: International Organizations in Global Politics, Ithaca, New York: Cornell University Press.

Barton, John H., Judith L. Goldstein, Timothy E. Josling ve Richard H. Steinberg (2006). The Evolution of the Trade Regime: Politics, Law, and Economics of the GATT and the WTO. Princeton, New Jersey: Princeton University Press.

Blyth, Mark (2001). Great Transformations: Economic Ideas and Institutional Change in the Twentieth Century, New York: Cambridge University Press.

Bourantonis, Dimitris (2005). The History and Politics of UN Security Council Reform, London: Routledge Press.

Callaghan, Helen ve Martin Höpner (2005). "European Integration and the Clash of Capitalisms: Political Cleavages over Takeover Liberalization", Comparative European Politics, Cilt 3 (3), ss. 30-32.

Capoccia, Giovanni ve R. Daniel Kelemen (2007). "The Study of Critical Junctures: Theory, Narrative, and Counterfactuals in Historical Institutionalism" World Politics, Cilt 59 (3), ss. 341-369.

Carlsnaes, Walter, Thomas Risse ve Beth A. Simmons (2002). Handbook of International Relations, London: Sage Press.

Crouch, Colin ve Henry Farrell (2004). "Breaking the Path of Institutional Development? Alternatives to the New Determinism in Political Economy", $R a$ tionality and Society, Cilt 16 (1), ss. 5-43.

Drezner, Daniel (2009). "The Power and Peril of International Regime Complexity" Perspectives on Politics, Cilt 7 (1), ss. 65-70.

Elman, Colin ve Elman, Miriam Fendius (2001). Bridges and Boundaries: Historians, Political Scientists, and the Study of International Relations, Cambridge, Massachusetts: MIT Press.

Falleti, Tulia G. ve Julia F. Lynch (2009). “Context and Causal Mechanisms in Political Analysis", Comparative Political Studies, Cilt 42 (9), ss. 11431166.

Farrell, Henry ve Abraham Newman (2010). "Making International Markets: Domestic Institutions in International Political Economy", Review of
International Political Economy, Cilt 17 (4), ss. 609638.

Finnemore, Martha ve Kathryn Sikkink (2001). "Taking Stock: The Constructivist Research Program in International Relations and Comparative Politics", Annual Review of Political Science, Cilt 4, ss. 391-416.

Frieden, Jeffry A. (1999). "Actors and Preferences in International Relations", (Strategic Choice and International Relations içinde), ed. David A. Lake ve Robert Powell, ss. 39-76, Princeton, New York: Princeton University Press.

Frieden, Jeffry A. ve Lisa Martin (2001). "International Political Economy: Global and Domestic Interactions", (Political Science: State of the Discipline içinde), ed. Ira Katznelson ve Helen V. Milner, ss.118-146, New York: Norton Press.

Garrett, Laurie (2007). "The Challenge of Global Health”, Foreign Affairs, Cilt 86 (1), ss. 14-38.

Gilpin, Robert (2001). Global Political Economy: Understanding the International Economic Order, Princeton, New Jersey: Princeton University Press.

Goldstein, Judith (1993). Ideas, Interests and American Trade Policy, Ithaca, New York: Cornell University Press.

Goldstein, Judith, Miles Kahler, Robert O. Keohane ve Anne-Marie Slaughter (2000). "Introduction: Legalization and World Politics", International Organization, Cilt 54 (3), ss. 1-15.

Hall, Peter A. (1993). "Policy Paradigms, Social Learning, and the State: The Case of Economic Policymaking in Britain", Comparative Politics, Cilt 25 (3), ss. 275-296.

Hobden, Stephen ve John M. Hobson (2002). Historical Sociology in International Relations, New York: Cambridge University Press.

Ikenberry, G. John (2001). After Victory: Institutions, Strategic Restraint, and the Rebuilding of Order After Major Wars, Princeton, New Jersey: Princeton University Press.

Ikenberry, G. John (2009). "Liberal Internationalism 3.0: America and the Dilemmas of Liberal World Order", Perspectives on Politics, Cilt 70 (1), ss. 71-87.

Jervis, Robert (1997). System Effects: Complexity in Political and Social Life, Princeton, New Jersey: Princeton University Press.

Kahler, Miles ve David A. Lake (2003). Governance in a Global Economy: Political Authority in Transition. Princeton, New Jersey: Princeton University Press.

Kahler, Miles ve David A. Lake (2009). "Economic Integration and Global Governance: Why So 
Little Supranationalism?" (The Politics of Global Regulations içinde), ed. Walter Mattli ve Ngaire Woods, ss. 242-276. Princeton, New Jersey: Princeton University Press.

Katzenstein, Peter J., Robert O. Keohane ve Stephen D. Krasner (1998). "International Organization and the Study of World Politics", International Organization, Cilt 52 (4), ss. 645-685.

Katznelson, Ira ve Barry R. Weingast (2005). “Intersections between Historical and Rational Choice Institutionalism", (Preferences and Situations: Points of Intersection between Historical and Rational Choice Institutionalism içinde), ed. Ira Katznelson ve Barry R. Weingast, ss. 1-26. New York: Russell Sage Foundation Press.

Keohane, Robert O. (1984). After Hegemony: Cooperation and Discord in the World Political Economy, Princeton, New Jersey: Princeton University Press.

Keohane, Robert O. (2008). "Big Questions in the Study of World Politics" (The Oxford Handbook of International Relations içinde), ed. Christian ReusSmit ve Duncan Snidal, ss. 708-715, New York: Oxford University Press.

Keohane, Robert O. ve Lisa L. Martin (2001). "Institutional Theory as a Research Program", (Progress in International Relations Theory: Appraising the Field içinde), ed. Colin Elman ve Elman Miriam Fendius, ss. 71-108, Cambridge, Massachusetts: MIT Press.

Lake, David (2002). "Progress in International Relations: Beyond Paradigms in the Study of Institutions", (Realism and Institutionalism in International Studies içinde), ed. Michael Brecher ve Frank P. Harvey, ss. 135-152. Ann Arbor: University of Michigan Press.

Lawson, George (2006). "The Promise of Historical Sociology in International Relations", International Studies Review, Cilt 8 (3), ss. 397-423.

Lindner, Johannes ve Berthold Rittberger (2003). "The Creation, Interpretation and Contestation of Institutions: Revisiting Historical Institutionalism", Journal of Common Market Studies, Cilt 41 (3), ss. 445-473.

Mahoney James, Erin Kimball ve Kendra L. Koivu (2009). "The Logic of Historical Explanation in the Social Sciences", Comparative Political Studies, Cilt 42 (1), ss.114-146.

Mahoney, James ve Dietrich Rueschemeyer (2003). Comparative Historical Analysis in the Social Sciences, New York: Cambridge University Press.

Mahoney, James ve Kathleen Thelen (2009). Explaining Institutional Change: Ambiguity, Agency, and Power, New York: Cambridge University Press.
Mansfield, Edward D. ve Jack Snyder (2005). Electing to Fight: Why Emerging Democracies Go to War, Cambridge, Massachusetts: MIT Press.

March, James G. ve Johan P. Olsen (1984). "The New Institutionalism: Organizational Factors in Political Life", American Political Science Review, Cilt 78 (3), ss. 734-749.

Martin, Lisa L. ve Beth A. Simmons (1998). “Theories and Empirical Studies of International Institutions", International Organization, Cilt 52 (4), ss. 729-757.

McNamara, Kathleen R. (1998). The Currency of Ideas: Monetary Politics in the European Union, Ithaca, New York: Cornell University Press.

Mearsheimer, John (1990). "Back to the Future: Instability of Europe After the Cold War", International Security, Cilt 15 (1), ss. 5-56.

Meunier, Sophie ve Kathleen R. McNamara (2007). Making History: European Integration and Institutional Change at Fifty. New York: Oxford University Press.

Milner, Helen V. (1998). "Rationalizing Politics: The Emerging Synthesis of International, American and Comparative Politics", International Organization, Cilt 52 (4), ss. 759-786.

Moravcsik, Andrew (1997). “Taking Preferences Seriously: A Liberal Theory of International Politics", International Organization, Cilt 51 (4), ss. 513-553.

Munuera, Gabriel (1994). Preventing armed conflict in Europe: lessons from recent experience, Institute for Security Studies Western European Union Press, Paris.

Newman, Abraham L. (2008). Protectors of Privacy: Regulating Personal Data in the Global Economy, Ithaca, New York: Cornell University Press.

Page, Scott (2006). "Path Dependence", Quarterly Journal of Political Science, Cilt 1 (1), ss. 87-115.

Philpott, Daniel (2001). Revolutions in Sovereignty: How Ideas Shaped Modern International Relations, Princeton, New Jersey: Princeton University Press.

Pierson, Paul (1993). "When Effect Becomes Cause: Policy Feedback and Political Change", World Politics, Cilt 45 (4), ss. 595-628.

Pierson, Paul (1996). "The Path to European Integration: A Historical-Institutionalist Analysis", Comparative Political Studies, Cilt 29 (2), ss. 123-163.

Pierson, Paul (2000). "Increasing Returns, Path Dependence, and the Study of Politics", American Political Science Review, Cilt 94 (2), ss. 251-267. 
Pierson, Paul (2004). Politics in Time: History, Institutions, and Social Analysis, Princeton, New Jersey: Princeton University Press.

Pierson, Paul ve Theda Skocpol (2001). "Historical Institutionalism in Contemporary Political Science", (Political Science: State of the Discipline içinde), ed. Ira Katznelson ve Helen V. Milner, ss. 693-721, New York: Norton Press.

Pollack, Mark A. (2006). "Rational Choice and EU Politics", (Handbook of European Union Politics içinde), ed. Knud Erik Jørgensen, Mark A. Pollack ve Ben Rosamond, ss. 31-56, London: Sage Press.

Raustiala, Kal (2009). Does the Constitution Follow the Flag? The Evolution of Territoriality in American Law, New York: Oxford University Press.

Raustiala, Kal ve David G. Victor (2004). "The Regime Complex for Plant Genetic Resources", International Organization, Cilt 58 (2), ss. 277-309.

Reus-Smit, Christian ve Duncan Snidal (2008). The Oxford Handbook of International Relations, Oxford, England: Oxford University Press.

Ruggie, John Gerard (2004). "Reconstituting the Global Public Domain: Issues, Actors, and Practices", European Journal of International Relations, Cilt 10 (4), ss. 499-531.

Sanders, Elizabeth (2006). "Historical Institutionalism", (The Oxford Handbook of Political Institutions içinde) ed. R. A. W. Rhodes, Sarah A. Binder ve Bert A. Rockman, ss. 39-55. New York: Oxford University Press.

Schickler, Eric (2001). Disjointed Pluralism: Institutional Innovation and the Development of the U.S. Congress. Princeton, New Jersey: Princeton University Press.

Shaffer, Gregory (2006). "The Challenges of WTO Law: Strategies for Developing Country Adaptation", World Trade Review, Cilt 5 (2), ss. 177-198.

Shanks, Cheryl, Harold K. Jacobson ve Jeffrey H. Kaplan (1996). "Inertia and Change in the Constellation of International Governmental Organizations, 1981-1992”, International Organization, Cilt 50 (4), ss. 593-627.

Singer, David Andrew (2007). Regulating Capital: Setting Standards for the International Financial System, Ithaca, New York: Cornell University Press.
Snidal, Duncan (2002). "Rational Choice and International Relations", (Handbook of International Relations içinde, ed. Walter Carlsnaes, Thomas Risse, ve Beth A. Simmons, ss. 73-94. London: Sage Press.

Solingen, Etel (2007). Nuclear Logics: Contrasting Paths in East Asia and the Middle East, Princeton, New Jersey: Princeton University Press.

Spruyt, Hendrik (1994). The Sovereign State and Its Competitors, Princeton, New Jersey: Princeton University Press.

Stein, Arthur (2008). "Neoliberal Institutionalism". (Oxford Handbook of International Relations içinde), ed. Christian Reus-Smit ve Duncan Snidal, ss. 201-221, New York: Oxford University Press.

Streeck, Wolfgang ve Kathleen Thelen (2005). "Introduction". (Beyond Continuity: Institutional Change in Advanced Capitalist Economies içinde), ed. Wolfgang Streeck ve Kathleen Thelen, ss. 1-39. New York: Oxford University Press.

Thelen, Kathleen (1999). "Historical Institutionalism in Comparative Politics", Annual Review of Political Scienc, Cilt 2, ss. 369-404.

Thelen, Kathleen (2004). How Institutions Evolve: The Political Economy of Skills in Germany, Britain, the United States, and Japan, New York: Cambridge University Press.

Tilly, Charles (1990). Coercion, Capital, and European States, AD 990-1992. Malden, Massachusetts: Blackwell Press.

Victor, David (2001). The Collapse of the Kyoto Protocol and the Struggle to Slow Global Warming, Princeton, New Jersey: Princeton University Press.

Wallander, Celeste A. (2000). "Institutional Assets and Adaptability: NATO After the Cold War", International Organization, Cilt 54 (4), 705-735.

Wendt, Alexander (1999). Social Theory of International Politics, New York: Cambridge University Press.

Woods, Ngaire, vd. (1996). Explaining International Relations Since 1945, Oxford, England: Oxford University Press. 